\title{
Physical Distancing and Hand Washing During the COVID-19 Pandemic: The role of fear, perceived seriousness, and health knowledge
}

Christian U. Krägeloh ( $\nabla$ chris.krageloh@aut.ac.nz )

Auckland University of Technology https://orcid.org/0000-0002-7298-0736

Mohsen Alyami

University of Auckland https://orcid.org/0000-0001-9278-1841

Hussain Alyami

Taif University https://orcid.org/0000-0001-5792-6638

Mohammed Alwaily

Najran University

Ahmed M. Alhuwaydi

Jouf University

Marcus A. Henning

University of Auckland https://orcid.org/0000-0002-1135-3464

\section{Research Article}

Keywords: Coronavirus, Fear of COVID-19 Scale, physical distancing, hand washing, Saudi Arabia

Posted Date: August 17th, 2020

DOl: https://doi.org/10.21203/rs.3.rs-59188/v1

License: (9) (i) This work is licensed under a Creative Commons Attribution 4.0 International License.

Read Full License

Version of Record: A version of this preprint was published at International Journal of Mental Health and Addiction on August 17th, 2020. See the published version at https://doi.org/10.1007/s11469-021-006740 . 


\section{Abstract}

Background: To reduce the spread of COVID-19, physical distancing and hand washing has been widely promoted. However, more work is needed to understand the predictors of compliance with such health behaviors, such as fear of COVID-19.

Methods: The Fear of COVID-19 Scale was administered to a sample of 1,029 Saudi participants recruited for an online survey. Analyses explored associations between fear of COVID-19 with demographic variables, frequency of physical distancing and hand washing, as well as perceived seriousness of COVID-19, and knowledge of recommended health behaviors and government restrictions.

Results: Frequency of physical distancing and hand washing was overall very high. Fear of COVID-19 did not predict health behaviors. Knowledge of government restrictions predicted both physical distancing and hand washing, while perceived seriousness of COVID-19 also had a weak association with hand washing.

Conclusion: Pandemic-related health behaviors such as physical distancing and hand washing do not appear to be motivated by fear in the present sample from Saudi Arabia. Interventions aimed at increasing compliance with recommended health behaviors thus benefit more from provision of relevant information.

\section{Introduction}

The outbreak of the novel coronavirus disease (COVID-19), caused by Severe Acute Respiratory Syndrome Coronavirus 2 (SARS-CoV-2), resulted in a major global health crisis prompting the World Health Organization to declare it as a global pandemic on the $11^{\text {th }}$ of March 2020 (Cucinotta and Vanelli 2020). At the time of writing this paper (June 2020), more than 7 million cases of COVID-19 had been reported around the world, and the pandemic is considered as being far from over (Nebehay and Farge 2020). Epicenters have shifted from China to Europe and most recently to the Americas and South Asia. While Oceania and some European countries are starting to experience a substantial reduction in new COVID-19 cases, other countries such as Brazil and India have continued growth in cases, while some countries such as Saudi Arabia have recorded a second surge (Johns Hopkins University \& Medicine 2020).

In addition to understanding the clinical course and mortality risks of COVID-19 (Bonow et al. 2020; Weiss and Murdoch 2020) as well as effective treatment options (Cunningham et al. 2020; Matthay et al. 2020; Sanders et al. 2020), efforts have been made to reduce the spread of the virus through implementing public health measures, promoting preventive behaviors, and increasing health literacy (Van den Broucke 2020; World Health Organization 2020a). The most drastic of these measures are government policies that severely limit movement of members of the public in order to reduce interpersonal contact. Travel restrictions and wide-spread lockdown have been implemented in spite of their staggering economic cost (Al-Awadhi et al. 2020; Ayittey et al. 2020; Ebrahim and Memish 2020), as such measures have been recognized and reported to be highly effective in mitigating the spread of the virus (Jarvis et al. 2020). In 
lockdown situations where face-to-face encounters are permitted, general recommendations have been to maintain a spatial distance of between 1.50 to $2.00 \mathrm{~m}$ (de Bruin et al. 2020).

Another common health measure to mitigate the spread of the virus has been the recommendation to engage in regular hand washing, using an alcohol-based hand rub or using soap and water when hands are visibly dirty (World Health Organization 2020b). Such recommendations have been specifically promoted in a wide range of settings including schools (Chen et al. 2020) and healthcare (Lotfinejad et al. 2020). Frequent hand washing has become so commonplace that it prompted calls to admonish people to engage in rational hand washing that balances adequate hygiene with the need to maintain skincare (Cavanagh and Wambier 2020). Hand washing may be a predictor for the spread of COVID-19: In countries where internet searches for the term "wash hands" had increased in frequency during the period 19 January to 18 February, COVID-19 spread more slowly during the month after (Lin et al. 2020).

Behavioral science has been described as playing a crucial role in understanding the factors influencing compliance with recommended health measures (Betsch 2020). A cross-sectional online study reported that US residents' behaviors such as purchasing more goods, attending large gatherings, or using facial masks were directly predicted by knowledge of COVID-19, with political orientation also playing a predictive role (Clements 2020). However, as fear of uncertainty and negative consequences is also known to be a key variable in effective health communication (Finset et al. 2020), Ahorsu et al. (2020) recently developed the Fear of COVID-19 Scale (FCV-19S). This scale has already been translated from its original Persian version to other languages such as Arabic (Alyami et al. 2020), Bangla (Sakib et al. 2020), English (Harper et al. 2020), Hebrew (Bitan et al. 2020), and Turkish (Satici et al. 2020), but studies are now needed to explore the function of fear of COVID-19 in relation to pandemic-related health behaviors. Studies using samples from New Zealand and the UK have reported that fear of COVID-19 could be a motivator for engaging in relevant health behaviors and adhering to lockdown rules (Harper et al. 2020; Winter et al. 2020). The present study extends exploration of the role of fear of COVID-19, perceived seriousness of COVID-19, and health knowledge to Saudi Arabia. Effects of these variables were investigated on physical distancing and hand washing as these are the most widely communicated health measures for individuals to mitigate the spread of COVID-19 (World Health Organization 2020a).

\section{Methods}

\section{Participants and procedure}

Participants were Saudi adults aged 18 years or older and recruited online using an anonymous survey administered using Google Forms. Study advertisements containing brief information about the study and a hyperlink to the study page were shared via email and personal and professional contacts and posted on social media sites including Twitter, Facebook, and Linkedln. Participants were asked to share the study with their personal and professional networks. Answers to all questionnaire items were required, and participants were able to submit their responses only if they had answered all questions. A total of 1,070 responses were received, of which 1,029 participants had completed all questionnaires. The mean 
age was 33.7 years $(S D=11.5)$. Male participants accounted for more than half of the sample $(52.7 \%)$. The majority of participants was married $(54.3 \%)$, had completed or was in the process of completing a university qualification (70.0\%), employed (47.2\%), and earned 9.999 Saudi Riyal or less a month (57.2\%). Participants were from all regions of Saudi Arabia, with the largest percentage (36\%) from the Western region of the country. Data were collected between 11 April and 11 May 2020. Participation was voluntary, and all participants provided electronic informed consent. This study had been reviewed and approved by the relevant ethics committee at Taif University (IRB 41-00155).

\section{Measures}

\section{Fear of COVID-19}

Participants' level of fear of COVID-19 was assessed using the Arabic version of the Fear of COVID-19 Scale (FCV-19S) (Alyami et al., 2020). The FCV-19S consists of 7 items (e.g., "I am most afraid of coronavirus-19" and "It makes me uncomfortable to think about coronavirus-19"). Each item is rated on a 5 -point scale, ranging from 1 (strongly disagree) to 5 (strongly agree). A total score is computed by adding all items with a possible total score ranging between 7 and 35 . Higher scores indicate greater levels of fear of COVID-19 (Ahorsu et al. 2020). Soon after the scale was published, it was translated and validated in several languages including Arabic (Alyami et al. 2020), Bangla (Sakib et al. 2020), English (Harper et al. 2020; Winter et al. 2020), Greek (Tsipropoulou et al. 2020), Hebrew (Bitan et al. 2020), Italian (Soraci et al. 2020), Russian (Reznik et al. 2020), and Turkish (Haktanir et al. 2020; Satici et al. 2020). The Arabic version of the FCV-19S had demonstrated robust psychometric properties (Alyami et al. 2020). Cronbach's alpha in the present study was .87.

\section{Perceived seriousness of COVID-19}

Participants' perceptions of the seriousness of COVID-19 was assessed using a single item that had been developed for the purpose of this study. The item asked participants to indicate, on a 5-point scale, the extent to which they agree or disagree with the following statement: "COVID-19 is a very serious disease for me, my loved ones, and the general population". Response options were 1 (strongly disagree), 2 (disagree), 3 (neither disagree nor agree), 4 (agree), and 5 (strongly agree).

\section{Knowledge of health behaviors and government restrictions}

Participants' knowledge was assessed using two items that had also been developed for the purpose of this study. Participants were asked about their knowledge of recommended public health measures ("How knowledgeable are you of the health actions recommended by the Ministry of Health to help reduce the spread of COVID-19"?) and their knowledge of restrictions enforced by the law ("How knowledgeable are you of the restrictions that the government has put in place to help reduce the spread 
of COVID-19"?). Each item is scored on a 4-point scale with 1 (not at all), 2 (know some), 3 (know most), and 4 (complete knowledge).

\section{Compliance with recommended health behaviors}

Participants' level of compliance with the recommended health behaviors, specifically, physical distancing and hand washing, was assessed using two items ("To what extent you do practice physical distancing (at least 2 meters) when you leave your safe bubble") and ("To what extent you do practice hand washing with soap and water for at least 20 seconds"). Each item is scored on a 5-point scale with 0 (not applicable), 1 (never), 2 (rarely), 3 (some of the time), and 4 (most of the time), with higher scores thus indicating greater compliance with physical distancing and hand-washing practices.

\section{Statistical analysis}

Statistical analyses were conducted using IBM SPSS Statistics v 26 software. Due to deviations from normality for some of the variables (as described below), group comparisons were conducted using nonparametric statistics. Nonparametric correlation analyses were conducted to provide a general overview of the pattern of associations among key variables of interest, which also permits more direct comparisons with other studies. Using a more targeted approach that controls for the presence of multiple variables, a multiple-linear regression explored the effects on health behaviors (physical distancing and hand washing) of demographic variables, fear of COVID-19, perceived seriousness of COVID-19, knowledge of recommended health behaviors, and knowledge of government restrictions. Regression is known to be robust against deviations from normality (Schmidt and Finan 2018), and multicollinearity was checked by inspecting values of variance inflation factor (Thompson et al. 2017).

\section{Results}

Table 1 shows, by demographic factors, mean scores for fear of COVID-19, perceived seriousness of COVID-19, frequency of physical distancing, frequency of hand washing, knowledge of recommended health behaviors, and knowledge of government restrictions. Apart from fear of COVID-19, all of the other variables presented with strong ceiling effects. For that reason, statistical comparisons of these variables by demographic factors were conducted using nonparametric statistics - Mann-Whitney U for variables with two factors (sex and marital status) and Kruskall Wallis for variables with more than two factors (education level, employment, monthly income, and region of residence). For each demographic variable, there was at least one significant effect for one of the variables of interest. For example, males had significantly lower scores on fear of COVID-19 than females, and single participants were significantly less likely to report engaging in frequent hand washing than married participants.

Nonparametric correlational analyses were conducted to provide an overview of the relationship among the variables of interest as well as the continuous demographic variable age (Table 2). Age was only very weakly correlated with frequency of hand washing and no other variable. Fear of COVID-19 was 
moderately correlated (Spearman's $r h o=.29$ ) with perceived seriousness of COVID-19 and had a weak negative correlation ( $r h o=-.11$ ) with both knowledge of recommended health behaviors and government restrictions. The only strong correlation found was between the two knowledge variables ( $r h o=.72)$.

The subsequent multiple-linear regression analyses explored which variables predicted frequency of physical distancing and hand washing. Because of the various effects by demographic variables as shown in Table 1, demographic variables were entered in the regression analysis as Block 1. For demographic variables with more than two factors, this required the creation of dummy variables prior to conducting the analyses. In Block 2, Fear of COVID-19, perceived seriousness of COVID-19, knowledge of recommended health behaviors, and knowledge of government restrictions were entered simultaneously. Given the high correlation between the two knowledge variables (Table 2), the potential for multicollinearity was explored. However, since variance inflation factor scores for these variables were around 2.30 and thus below the commonly used cut-off value of 10.00 or even the more conservative cutoff value of 3.00 (Thompson et al. 2017), multicollinearity was deemed to be of no concern.

Table 3 shows the results of two regression analyses, one with physical distancing and the other one with hand washing as outcome variable. In both cases, the demographic variables of Block 1 were only very weak predictors. For physical distancing, sex and having a Bachelor education were significant predictors, although not sufficiently strong to result in a significant increase in $\mathrm{r} 2$ for that block. For hand washing, age was the only significant predictor variable $(\beta=.12)$, resulting in an $r 2$ increase of .04 for that block. Fear of COVID-19 was not a significant predictor for either of the two outcome variables. Knowledge of government restrictions significantly predicted physical distancing $(\beta=.16)$ and hand washing $(\beta=.23)$.

Perceived seriousness of COVID-19 was also significantly associated with hand washing $(\beta=.10)$, but no other Block 2 variable was a significant predictor of physical distancing.

\section{Discussion}

The purpose of the present study was to investigate the role of fear of COVID-19 alongside perceived seriousness of COVID-19 and knowledge of recommended health behaviors and government restrictions in their ability to predict to what extent individuals are engaging in physical distancing and hand washing. Previous work has explored associations between health behaviors and scores on the Fear of COVID-19 scale (Ahorsu et al. 2020) in a UK sample (Harper et al. 2020), and here we extended such investigations to a sample from Saudi Arabia. Unlike Harper et al. (2020), who reported a weak to moderate $(\beta=.20)$ effect of fear of COVID-19 on pandemic-related health behavior change, our study found no associations between fear of COVID-19 and physical distancing and hand washing. Our result is also in contrast with another study where the authors reported weak correlations ( $r h o=.20$ and $r h o=.11$ ) between fear of COVID-19 and adherence to 2-m physical distancing in two samples collected in New Zealand (Winter et al. 2020).

Given the known effectiveness of fear as a motivator for behavior change (Tannenbaum et al. 2015) and the above-mentioned reports of associations between fear of COVID-19 and relevant health behaviors, our 
results may appear unexpected. However, it needs to be noted that the associations reported in the UK (Harper et al. 2020) and New Zealand (Winter et al. 2020) should still be considered relatively small, and the discrepancies between these reports and our findings from Saudi Arabia must therefore not be exaggerated. Lack of predictive effects may well be related to the fact that frequency of physical distancing and hand washing was overall high in the present sample, resulting in a ceiling effect. This finding indicates that compliance with recommended health behaviors is generally very high in Saudi Arabia, which is also consistent with reports that the infection control measures in Saudi Arabia are generally well perceived (Alhajji et al. 2020).

Instead of an association between fear of COVID-19 and health behaviors, our study found that knowledge of government restrictions predicted physical distancing and hand washing, and perceived seriousness of COVID-19 was also a predictor for hand washing (Table 3). However, the effects were also relatively small, and the overall $r^{2}$ for the two regressions was almost negligible. Again, this may be due to the fact that knowledge of recommended health behaviors and restrictions was generally very high. There is certainly a possibility that this finding is a reflection of a sampling bias that resulted in a reduced likelihood of participants of lower socioeconomic status being included. In a study from Iran, medical students, who also generally tend to be from higher socioeconomic backgrounds, were also found to have a high degree of COVID-19-related knowledge (Taghrir et al. 2020). It appears likely, however, that risk perception related to fatality and seriousness of the virus is sufficient to motivate pandemic-related health behaviors (Niepel et al. 2020) rather than full-blown fear. In the context of the 2009 swine flu pandemic, factors influencing recommended behavior changes were also reported to be risk of catching the disease as well as control over risk and trust in authorities (Rubin et al. 2009). For pandemic-related health communication to be effective, inducing fear of pandemic is therefore not essential.

The following limitations need to be acknowledged. First, being a cross-sectional design, causality cannot be inferred. Second, data collection relied on snowball sampling, which was practical during the isolation and lockdown measures imposed at the time by the Government. This sampling method may thus have introduced selection bias due to only some individuals receiving the online invitation to participate in the study. Third, frequency of physical distancing and hand washing was assessed by only one item each, thus not allowing for differentiation of these health behaviors by context. A more detailed assessment of these health behaviors may have revealed slightly different associations with fear of COVID-19, perceived seriousness, and knowledge variables. Lastly, the participants tended to be more highly educated than the general population. Further studies using a more representative sample of the general population of Saudi Arabia are thus required.

\section{Declarations}

\section{Conflict of Interest}

The authors declare that they have no conflict of interest. 


\section{Ethical approval}

All procedures followed were in accordance with the ethical standards of the responsible committee on human experimentation (institutional and national) and with the Helsinki Declaration. This study was reviewed and approved by the appropriate ethics committee at Taif University, Saudi Arabia (IRB 4100155)

\section{Informed Consent}

All participants provided electronic informed consent.

\section{Funding}

No funding was sought.

\section{References}

Ahorsu, D. K., Lin, C.-Y., Imani, V., Saffari, M., Griffiths, M. D., \& Pakpour, A. H. (2020). The Fear of COVID-19 Scale: Development and initial validation. International Journal of Mental Health and Addiction. https://doi.org/10.1007/s11469-020-00270-8

Alhajji, M., Al Khalifah, A., Aljubran, M. J., \& Alkhalifah, M. (2020). Sentiment analysis of tweets in Saudi Arabia regarding governmental preventive measures to contain COVID-19. Preprints, 2020, 2020040031. https://doi.org/10.20944/preprints202004.0031.v1

Al-Awadhi, A. M., Alsaifi, K., Al-Awadhi, A., \& Alhammadi, S. (2020). Death and contagious infectious diseases: Impact of the COVID-19 virus on stock market returns. Journal of Behavioral and Experimental Finance, 27, 100326. https://doi.org/10.1016/j.jbef.2020.100326

Alyami, M., Henning, M., Krägeloh, C. U., \& Alyami, H. (2020). Psychometric evaluation of the Arabic version of the Fear of COVID-19 Scale. International Journal of Mental Health and Addiction. https://doi.org/10.1007/s11469-020-00316-x

Ayittey, F. K., Ayittey, M. K., Chiwero, N. B., Kamasah, J. S., \& Dzuvor, C. (2020). Economic impacts of Wuhan 2019-nCoV on China and the world. Journal of Medical Virology, 92(5), 473-475. https://doi.org/10.1002/jmv.25706

Betsch, C. (2020). How behavioural science data helps mitigate the COVID-19 crisis. Nature Human Behaviour, 4(5), 438. https://doi.org/10.1038/s41562-020-0866-1

Bitan, D. T., Grossman-Giron, A., Bloch, Y., Mayer, Y., Shiffman, N., \& Mendlovic, S. (2020). Fear of COVID19 scale: Psychometric characteristics, reliability and validity in the Israeli population. Psychiatry Research, 289, 113100. https://doi.org/10.1016/j.psychres.2020.113100 
Bonow, R. O., Fonarow, G. C., O'Gara, P. T., \& Yancy, C. W. (2020). Association of Coronavirus Disease 2019 (COVID-19) with myocardial injury and mortality. JAMA Cardiology. https://doi.org/10.1001/jamacardio.2020.1105

Cavanagh, G., \& Wambier, C. G. (2020). Rational hand hygiene during the coronavirus 2019 (COVID-19) pandemic. Journal of the American Academy of Dermatology, 82(6), e211.

https://doi.org/10.1016/j.jaad.2020.03.090

Chen, X., Ran, L., Liu, Q., Hu, Q., Du, X., \& Tan, X. (2020). Hand hygiene, mask-wearing behaviors and its associated factors during the COVID-19 epidemic: a cross-sectional study among primary school students in Wuhan, China. International Journal of Environmental Research and Public Health, 17, 2893. https://doi.org/10.3390/ijerph17082893

Clements, J. M. (2020). Knowledge and behaviors toward COVID-19 among US residents during the early days of the pandemic: cross-sectional online questionnaire. JMIR Public Health and Surveillance, 6(2), e19161. https://doi.org/10.2196/19161

Cucinotta, D., \& Vanelli, M. (2020). WHO declares COVID-19 a pandemic. Acta Bio-Medica: Atenei Parmensis, 91(1), 157-160. https://doi.org/10.23750/abm.v91i1.9397

Cunningham, A. C., Goh, H. P., \& Koh, D. (2020). Treatment of COVID-19: old tricks for new challenges. Critical Care, 24, 91. https://doi.org/10.1186/s13054-020-2818-6

de Bruin, Y. B., Lequarre, A.-S., McCourt, J., Clevestig, P., Pigazzani, F., Jeddi, M. Z., Colosio, C., \& Goulart, M. (2020). Initial impacts of global risk mitigation measures taken during the combatting of the COVID-19 pandemic. Safety Science, 128, 104773. https://doi.org/10.1016/j.ssci.2020.104773

Ebrahim, S. H., \& Memish, Z. A. (2020). Saudi Arabia's drastic measures to curb the COVID-19 outbreak: temporary suspension of the Umrah pilgrimage. International Society of Travel Medicine, 27(3), 1-2. https://doi.org/10.1093/jtm/taaa029

Finset, A., Bosworth, H., Butow, P., Gulbrandsen, P., Hulsman, R. L., Pieterse, A. H., \& Street, R. (2020). Effective health communication - a key factor in fighting the COVID-19 pandemic. Patient Education and Counseling, 103, 873-876. https://doi.org/10.1016/j.pec.2020.03.027

Haktanir, A., Seki, T., \& Dilmaç, B. (2020). Adaptation and evaluation of Turkish version of the fear of COVID-19 Scale. Death Studies. https://doi.org/10.1080/07481187.2020.1773026

Harper, C. A., Satchell, L. P., Fido, D., \& Latzman, R. D. (2020). Functional Fear Predicts Public Health Compliance in the COVID-19 Pandemic. International Journal of Mental Health and Addiction. https://doi.org/10.1007/s11469-020-00281-5

Jarvis, C. I., Van Zandvoort, K., Gimma, A., Prem. K., CMMID COVID-10 working group, Klepac, P., Rubin, G. J., \& Edmunds, W. J. (2020). Quantifying the impact of physical distance measures on the transmission 
of COVID-19 in the UK. BMC Medicine, 18, 124. https://doi.org/10.1186/s12916-020-01597-8

Johns Hopkins University \& Medicine (2020). Coronavirus Resource Center. Retrieved on 10 June 2020 from https://coronavirus.jhu.edu/map.html

Lin, Y.-H., Liu, C.-H., \& Chiu, Y.-C. (2020). Google searches for the keywords of "wash hands" predict the speed of national spread of COVID-19 outbreak among 21 countries. Brain, Behavior, and Immunity. https://doi.org/10.1016/j.bbi.2020.04.020

Lotfinejad, N., Peters, A., \& Pittet, D. (2020). Hand hygiene and the novel coronavirus pandemic: the role of healthcare workers. Journal of Hospital Infection. https://doi.org/10.1016/j.jhin.2020.03.017

Matthay, M. A., Aldrich, J. M., \& Gotts, J. E. (2020). Treatment for severe acute respiratory distress syndrome from COVID-19. Lancet Respiratory Medicine, 8(5), 433-434. https://doi.org/10.1016/S22132600(20)30127-2

Nebehay, S, \& Farge, E. (2020). WHO says pandemic 'far from over' as daily cases hit record high. Retrieved on 10 June 2020 from https://www.reuters.com/article/us-health-coronavirus-who/who-sayspandemic-far-from-over-as-daily-cases-hit-record-high-idUSKBN23F23E

Niepel, C., Kranz, D., Borgonovi, F., Emslander, V., \& Greiff, S. (2020). The coronavirus (COVID-19) fatality risk perception of US adult residents in March and April 2020. British Journal of Health Psychology. https://doi.org/10.1111/bjhp.12438

Reznik, A., Gritsenko, V., Konstantinov, V., Khamenka, N., \& Isralowitz, R. (2020). COVID-19 fear in Eastern Europe: Validation of the Fear of COVID-19 Scale. International Journal of Mental Health and Addiction. https://doi.org/10.1007/s11469-020-00283-3

Rubin, G. J., Amlôt, R., Page, L., \& Wessely, S. (2015). Public perceptions, anxiety, and behaviour change in relation to the swine flu outbreak: cross sectional telephone survey. BMJ, 339, b2651, https://doi.org/ 10.1136/bmj.b2651 区

Sakib, N., Mamun, M. A., Bhuiyan, A. I., Hossain, S., Al Mamun, F., Hosen, I., Abdullah, A. H., Sarker, A., Mohiuddin, M. S., Rayhan, I., Hossain, M., Sikder, T., Gozal, D., Muhit, M. A., Islam, S. M. S., Griffiths, M. D., \& Pakpour, A. H. (2020). Psychometric validation of the Bangla Fear of COVID-19 Scale: Confirmatory factor analysis and Rasch analysis. International Journal of Mental Health and Addiction. https://doi.org/10.1007/s11469-020-00289-x

Sanders, J. M., Monogue, M. L., Jodlowski, T. Z., \& Cutrell, B. (2020). Pharmacologic treatments for Coronavirus Disease 2019 (COVID-19) - a review. JAMA, 323(18), 1824-1836.

https://doi.org/10.1001/jama.2020.6019 
Satici, B., Gocet-Tekin, E., Deniz, M. E., \& Satici, S. A. (2020). Adaptation of the Fear of COVID-19 Scale: Its association with psychological distress and life satisfaction in Turkey. International Journal of Mental Health and Addiction. https://doi.org/10.1007/s11469-020-00294-0

Schmidt, A. F., \& Finan, C. (2018). Linear regression and the normality assumption. Journal of Clinical Epidemiology, 98, 146-151. https://doi.org/10.1016/j.jclinepi.2017.12.006

Soraci, P., Ferrari, A., Abbiati, F. A., Del Fante, E., De Pace, R., Urso, A., \& Griffiths, M. D. (2020). Validation and psychometric evaluation of the Italian version of the Fear of COVID-19 Scale. International Journal of Mental Health and Addiction. https://doi.org/10.1007/s11469-020-00277-1

Taghrir, M., Borazjani, R., \& Shiraly, R. (2020). COVID-19 and Iranian medical students; a survey on their related-knowledge, preventive behaviors and risk perception. Archives of Iranian Medicine, 23(4), $249-254$. https://doi.org/10.34172/aim.2020.06

Tannenbaum, M. B., Hepler, J., Zimmerman, R. S., Saul, L., Jacobs, S., Wilson, K., \& Albarracín, D. (2015). Appealing to fear: A meta-analysis of fear appeal effectiveness \and theories. Psychological Bulletin, 141(6), 1178-1204, https://doi.org/ 10.1037/a0039729 》

Thompson, C. G., Kim, R. S., Aloe, A. M., \& Becker, B. J. (2017). Extracting the variance inflation factor and other multicollinearity diagnostics from typical regression results. Basic and Applied Social Psychology, 39(2), 81-90. https://doi.org/10.1080/01973533.2016.1277529

Tsipropoulou, V., Nikopoulou, V. A., Holeva, V., Nasika, Z., Diakogiannis, I., Sakka, S., Kostikidou, S., Varvara, C., Spyridopoulou, E., \& Parlapani, E. (2020). Psychometric properties of the Greek version of FCV-19S. International Journal of Mental Health and Addiction. https://doi.org/10.1007/s11469-02000319-8

Van den Broucke, S. (2020). Why health promotion matters to the COVID-19 pandemic, and vice versa. Health Promotion International, 35(2), 181-186. https://doi.org/10.1093/heapro/daaa042

Weiss, P., \& Murdoch, D. R. (2020). Clinical course and mortality risk of severe COVID-19. Lancet, 395(10229), 1014-1015. https://doi.org/10.1016/S0140-6736(20)30633-4

Winter, T., Riordan, B. C., Pakpour, A. H., Griffiths, M. D., Mason, A., Poulgrain, J. W., \& Damian, S. (2020). Evaluation of the English version of the Fear of COVID-19 Scale and its relationship with behavior change and political beliefs. International Journal of Mental Health and Addiction.

https://doi.org/10.1007/s11469-020-00342-9

World Health Organization (2020a). Coronavirus disease (COVID-19) advice for the public. Retrieved on 10 June 2020 from https://www.who.int/emergencies/diseases/novel-coronavirus-2019/advice-forpublic 
World Health Organization (2020b). Advice on the use of masks in the community, during home care, and in health care settings in the context of COVID-19: interim guidance, 19 March 2020. Retrieved on 10 June 2020 from https://apps.who.int/iris/handle/10665/331493

\section{Tables}

Table 1. Means and standard deviation (in parentheses) by demographic variables 


\begin{tabular}{|c|c|c|c|c|c|c|}
\hline Characteristics & $\begin{array}{c}\text { Fear of } \\
\text { COVID- } \\
19\end{array}$ & $\begin{array}{c}\text { Perceived } \\
\text { seriousness }\end{array}$ & $\begin{array}{c}\text { Knowledge } \\
\text { of health } \\
\text { behaviors }\end{array}$ & $\begin{array}{l}\text { Knowledge } \\
\text { of } \\
\text { restrictions }\end{array}$ & $\begin{array}{c}\text { Physical } \\
\text { distancing }\end{array}$ & $\begin{array}{c}\text { Hand } \\
\text { washing }\end{array}$ \\
\hline \multicolumn{7}{|l|}{ Sex } \\
\hline Male $(n=542)$ & $\begin{array}{l}16.37 \\
(5.60)\end{array}$ & $4.23(0.96)$ & $3.62(0.63)$ & $3.70(0.59)$ & $\begin{array}{c}3.58 \\
(0.73)\end{array}$ & $\begin{array}{c}3.61 \\
(0.78)\end{array}$ \\
\hline $\begin{array}{c}\text { Female } \\
(n=487)\end{array}$ & $\begin{array}{l}17.13 \\
(5.73)\end{array}$ & $4.20(0.97)$ & $3.67(0.61)$ & $3.76(0.54)$ & $\begin{array}{c}3.69 \\
(0.80)\end{array}$ & $\begin{array}{c}3.65 \\
(0.72)\end{array}$ \\
\hline$p$-value ${ }^{a}$ & $<.05^{*}$ & $>.05$ & $>.05$ & $>.05$ & $<.01 * *$ & $>.05$ \\
\hline \multicolumn{7}{|l|}{ Marital status ${ }^{b}$} \\
\hline $\begin{array}{c}\text { Single } \\
(n=430)\end{array}$ & $\begin{array}{l}16.70 \\
(5.97)\end{array}$ & $4.20(0.99)$ & $3.58(0.65)$ & $3.68(0.60)$ & $\begin{array}{c}3.60 \\
(0.79)\end{array}$ & $\begin{array}{c}3.52 \\
(0.88)\end{array}$ \\
\hline $\begin{array}{l}\text { Married } \\
(n=559)\end{array}$ & $\begin{array}{l}16.84 \\
(5.34) \\
\end{array}$ & $4.23(0.94)$ & $3.68(0.60)$ & $3.77(0.54)$ & $\begin{array}{c}3.65 \\
(0.76) \\
\end{array}$ & $\begin{array}{c}3.70 \\
(0.65) \\
\end{array}$ \\
\hline$p$-value ${ }^{\mathrm{a}}$ & $>.05$ & $>.05$ & $<.01 * *$ & $<.01 * *$ & $>.05$ & $<.01 * *$ \\
\hline \multicolumn{7}{|l|}{$\begin{array}{l}\text { Education } \\
\text { level }\end{array}$} \\
\hline $\begin{array}{l}\text { High school } \\
\text { or less } \\
(n=214)\end{array}$ & $\begin{array}{l}17.15 \\
(5.48)\end{array}$ & $4.33(0.96)$ & $3.66(0.64)$ & $3.69(0.64)$ & $\begin{array}{c}3.51 \\
(0.93)\end{array}$ & $\begin{array}{c}3.61 \\
(0.80)\end{array}$ \\
\hline $\begin{array}{l}\text { Diploma } \\
(n=94)\end{array}$ & $\begin{array}{l}16.84 \\
(6.50)\end{array}$ & $4.27(1.06)$ & $3.68(0.71)$ & $3.74(0.60)$ & $\begin{array}{c}3.56 \\
(0.78)\end{array}$ & $\begin{array}{c}3.57 \\
(0.76)\end{array}$ \\
\hline $\begin{array}{l}\text { Bachelor } \\
(n=522)\end{array}$ & $\begin{array}{r}16.75 \\
(5.81) \\
\end{array}$ & $4.25(0.91)$ & $3.60(0.62)$ & $3.72(0.55)$ & $\begin{array}{c}3.66 \\
(0.70) \\
\end{array}$ & $\begin{array}{c}3.62 \\
(0.74) \\
\end{array}$ \\
\hline $\begin{array}{l}\text { Master/PhD } \\
(n=199)\end{array}$ & $\begin{array}{l}16.18 \\
(5.08) \\
\end{array}$ & $3.96(1.04)$ & $3.73(0.55)$ & $3.79(0.51)$ & $\begin{array}{c}3.72 \\
(0.72) \\
\end{array}$ & $\begin{array}{c}3.70 \\
(0.72) \\
\end{array}$ \\
\hline$p$-value ${ }^{c}$ & $>.05$ & $<.01$ ** & $<.01 * *$ & $>.05$ & $<.05^{*}$ & $>.05$ \\
\hline \multicolumn{7}{|l|}{ Employment } \\
\hline $\begin{array}{l}\text { Student } \\
(n=311)\end{array}$ & $\begin{array}{l}16.46 \\
(5.90) \\
\end{array}$ & $4.22(1.02)$ & $3.57(0.67)$ & $3.67(0.62)$ & $\begin{array}{c}3.62 \\
(0.81) \\
\end{array}$ & $\begin{array}{c}3.51 \\
(0.91) \\
\end{array}$ \\
\hline $\begin{array}{l}\text { Employed } \\
(n=486)\end{array}$ & $\begin{array}{c}16.71 \\
(5.67) \\
\end{array}$ & $4.19(0.96)$ & $3.70(0.59)$ & $3.77(0.53)$ & $\begin{array}{c}3.66 \\
(0.71) \\
\end{array}$ & $\begin{array}{c}3.67 \\
(0.71) \\
\end{array}$ \\
\hline $\begin{array}{l}\text { Unemployed } \\
(n=169)\end{array}$ & $\begin{array}{l}17.25 \\
(5.52)\end{array}$ & $4.20(0.95)$ & $3.69(0.57)$ & $3.76(0.54)$ & $\begin{array}{c}3.60 \\
(0.91)\end{array}$ & $\begin{array}{c}3.62 \\
(0.65)\end{array}$ \\
\hline $\begin{array}{l}\text { Retired } \\
(n=63)\end{array}$ & $\begin{array}{l}16.84 \\
(4.97) \\
\end{array}$ & $4.43(0.73)$ & $3.52(0.67)$ & $3.63(0.66)$ & $\begin{array}{c}3.63 \\
(0.60) \\
\end{array}$ & $\begin{array}{c}3.87 \\
(0.34) \\
\end{array}$ \\
\hline$p$-value ${ }^{\mathrm{c}}$ & $<.05^{*}$ & $>.05$ & $<.01^{* *}$ & $<.05 *$ & $>.05$ & $<.01^{* *}$ \\
\hline Monthly & & & & & & \\
\hline
\end{tabular}




\begin{tabular}{|c|c|c|c|c|c|c|}
\hline \multicolumn{7}{|l|}{ income $^{\mathrm{d}}$} \\
\hline $\begin{array}{l}9.999 \text { or less } \\
(n=589)\end{array}$ & $\begin{array}{l}16.79 \\
(5.90)\end{array}$ & $4.25(0.95)$ & $3.60(0.67)$ & $3.70(0.61)$ & $\begin{array}{c}3.59 \\
(0.82)\end{array}$ & $\begin{array}{c}3.56 \\
(0.80)\end{array}$ \\
\hline \begin{tabular}{|l}
$10,000-$ \\
15,999 \\
$(n=208)$
\end{tabular} & $\begin{array}{l}16.80 \\
(5.16)\end{array}$ & $4.23(0.99)$ & $3.74(0.53)$ & $3.81(0.45)$ & $\begin{array}{c}3.66 \\
(0.77)\end{array}$ & $\begin{array}{c}3.68 \\
(0.73)\end{array}$ \\
\hline $\begin{array}{c}16,000 \text { or } \\
\text { more }(n=232)\end{array}$ & $\begin{array}{l}16.53 \\
(5.54)\end{array}$ & $4.11(0.99)$ & $3.68(0.55)$ & $3.74(0.55)$ & $\begin{array}{c}3.72 \\
(0.63)\end{array}$ & $\begin{array}{c}3.75 \\
(0.61)\end{array}$ \\
\hline$p$-value ${ }^{\mathrm{c}}$ & $>.05$ & $>.05$ & $<.05^{*}$ & $>.05$ & $>.05$ & $<.01 * *$ \\
\hline \multicolumn{7}{|l|}{ Region } \\
\hline $\begin{array}{c}\text { Central } \\
(n=227)\end{array}$ & $\begin{array}{l}17.09 \\
(5.83) \\
\end{array}$ & $4.20(0.99)$ & $3.67(0.61)$ & $3.80(0.49)$ & $\begin{array}{c}3.70 \\
(0.76) \\
\end{array}$ & $\begin{array}{c}3.69 \\
(0.65) \\
\end{array}$ \\
\hline $\begin{array}{l}\text { Northern } \\
(n=77)\end{array}$ & $\begin{array}{l}17.12 \\
(5.15)\end{array}$ & $4.31(0.80)$ & $3.58(0.64)$ & $3.71(0.51)$ & $\begin{array}{c}3.65 \\
(0.82)\end{array}$ & $\begin{array}{c}3.68 \\
(0.68)\end{array}$ \\
\hline $\begin{array}{l}\begin{array}{l}\text { Southern } \\
(n=241)\end{array} \\
\end{array}$ & $\begin{array}{l}16.55 \\
(6.17) \\
\end{array}$ & $4.17(1.07)$ & $3.62(0.67)$ & $3.68(0.63)$ & $\begin{array}{c}3.53 \\
(0.82) \\
\end{array}$ & $\begin{array}{c}3.53 \\
(0.84) \\
\end{array}$ \\
\hline $\begin{array}{c}\text { Eastern } \\
(n=114)\end{array}$ & $\begin{array}{l}16.03 \\
(5.24) \\
\end{array}$ & $4.18(0.94)$ & $3.65(0.61)$ & $3.71(0.59)$ & $\begin{array}{c}3.68 \\
(0.71) \\
\end{array}$ & $\begin{array}{c}3.68 \\
(0.63) \\
\end{array}$ \\
\hline $\begin{array}{l}\text { Western } \\
(n=370)\end{array}$ & $\begin{array}{l}16.77 \\
(5.48) \\
\end{array}$ & $4.24(0.92)$ & $3.65(0.60)$ & $3.73(0.57)$ & $\begin{array}{c}3.65 \\
(0.74) \\
\end{array}$ & $\begin{array}{c}3.62 \\
(0.80) \\
\end{array}$ \\
\hline$p$-value ${ }^{\mathrm{c}}$ & $>.05$ & $>.05$ & $>.05$ & $>.05$ & $<.05^{*}$ & $>.05$ \\
\hline
\end{tabular}

aMann-Whitney U Test; ${ }^{b}$ due to small numbers of participants being divorced $(n=34)$ and widowed $(n=6)$, these categories were not included in the above analyses; ${ }^{C}$ Kruskall Wallis Test; ${ }^{d}$ Saudi Riyal; ${ }^{*} p<.05$; $\star \star p<.01$

Table 2. Spearman's Rho correlation matrix of the variables age, total fear of COVID-19 scores, perceived seriousness of COVID-19, knowledge of recommended health behaviors, knowledge of government restrictions, frequency of physical distancing, and frequency of hand washing. 


\begin{tabular}{|c|c|c|c|c|c|c|}
\hline Variable & Age & $\begin{array}{c}\text { Fear of } \\
\text { COVID- } \\
19\end{array}$ & $\begin{array}{c}\text { Perceived } \\
\text { seriousness }\end{array}$ & $\begin{array}{c}\text { Knowledge of } \\
\text { health } \\
\text { behaviors }\end{array}$ & $\begin{array}{l}\text { Knowledge } \\
\text { of } \\
\text { restrictions }\end{array}$ & $\begin{array}{c}\text { Hand } \\
\text { washing }\end{array}$ \\
\hline Age & - & & & & & \\
\hline $\begin{array}{l}\text { Fear of COVID- } \\
19\end{array}$ & .02 & - & & & & \\
\hline $\begin{array}{l}\text { Perceived } \\
\text { seriousness }\end{array}$ & -.02 & $29^{* *}$ & - & & & \\
\hline $\begin{array}{l}\text { Knowledge of } \\
\text { health } \\
\text { behaviors }\end{array}$ & .05 & $-.11^{* *}$ & .01 & - & & \\
\hline $\begin{array}{l}\text { Knowledge of } \\
\text { restrictions }\end{array}$ & .04 & $-.11^{* *}$ & .02 & $.72^{* *}$ & - & \\
\hline Hand washing & $.14^{* *}$ & -.01 & $.12^{* *}$ & $.21^{* *}$ & $.25^{* *}$ & - \\
\hline $\begin{array}{l}\text { Physical } \\
\text { distancing }\end{array}$ & .03 & -.03 & .01 & $.17^{* *}$ & $.22^{* *}$ & $.33^{* *}$ \\
\hline
\end{tabular}

${ }^{* \star} p<.01$

Table 3. Predictors of compliance with physical distancing and hand washing 


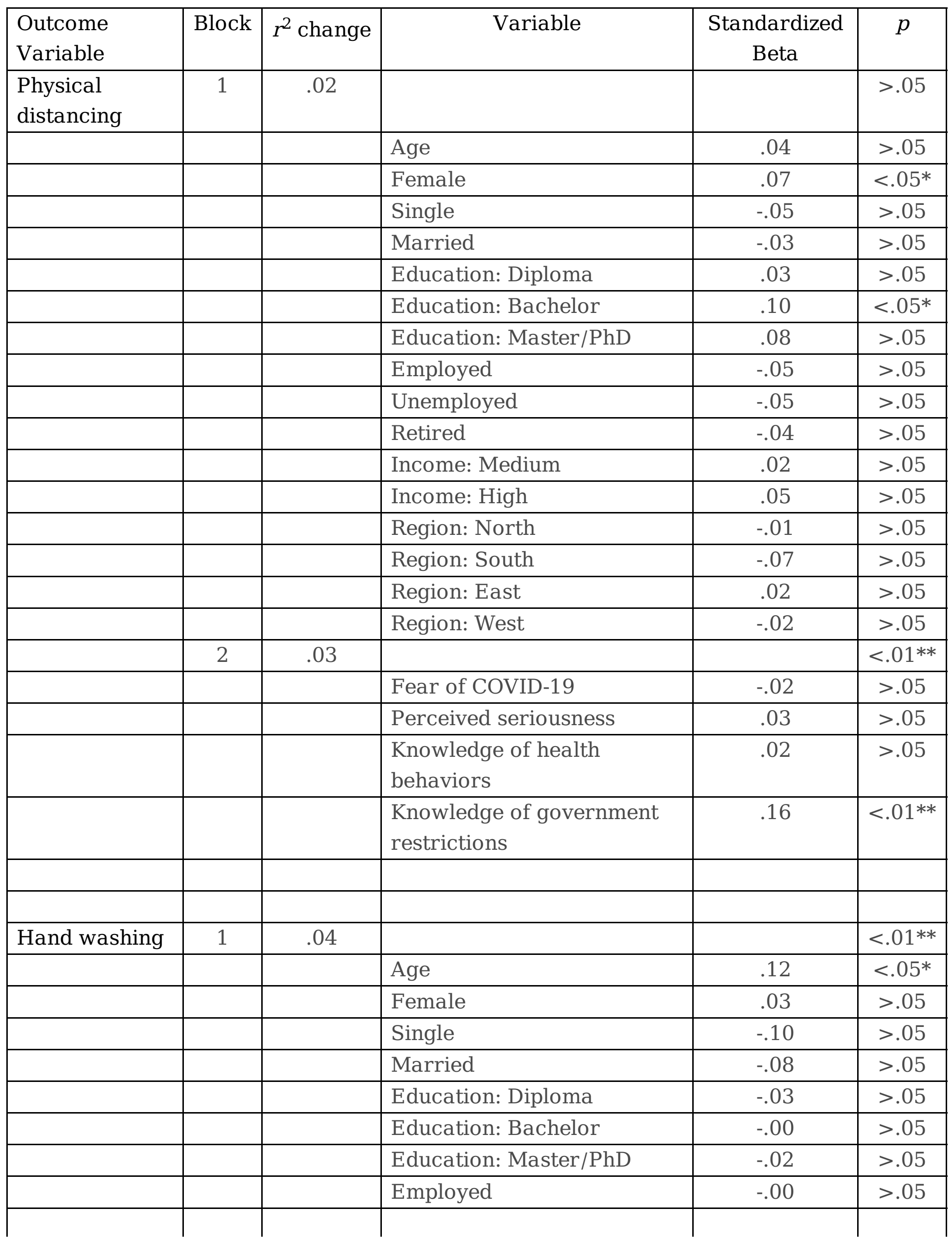




\begin{tabular}{|l|l|l|l|c|c|} 
& & & Unemployed & -.01 & $>.05$ \\
\hline & & & Retired & .01 & $>.05$ \\
\hline & & & Income: Medium & .03 & $>.05$ \\
\hline & & & Income: High & .06 & $>.05$ \\
\hline & & & Region: North & -.02 & $>.05$ \\
\hline & & & Region: South & -.09 & $>.05$ \\
\hline & & & Region: East & -.01 & $>.05$ \\
\hline & 2 & .07 & Region: West & -.06 & $>.05$ \\
\hline & & & Fear of COVID-19 & .02 & $>.01^{* *}$ \\
\hline & & $\begin{array}{l}\text { Perceived seriousness of } \\
\text { Covid-19 }\end{array}$ & .10 & $<.01^{* *}$ \\
\hline & & $\begin{array}{l}\text { Knowledge of health } \\
\text { behaviors }\end{array}$ & .02 & $>.05$ \\
\hline & & $\begin{array}{l}\text { Knowledge of government } \\
\text { restrictions }\end{array}$ & .23 & $<.01^{* *}$ \\
\hline
\end{tabular}

Standardized beta coefficients for two separate multiple-linear regressions with frequency of physical distancing and hand washing as outcome variables. In Block 1, demographic variables were entered as dummy variables where necessary. In Block 2, the following variables were entered: total score of the Fear of COVID-19 scale, perceived seriousness of COVID-19, knowledge of health behaviors, and knowledge of government restrictions.

${ }^{\star} p<.05 ;{ }^{*} p<.01$ 